\title{
Transatlantica
}

Revue d'études américaines. American Studies Journal

$1 \mid 2012$

Le roman policier, littérature transatlantique / Maisons

Hantées

\section{Vanessa Place: An Interview In Paris}

University of Paris 13, Sorbonne Paris Cité, June $7^{\text {th }}, 2012$

Marion Charret-Del Bove et Françoise Palleau-Papin

\section{(2) OpenEdition}

\section{Journals}

Édition électronique

URL : https://journals.openedition.org/transatlantica/5724

DOI : $10.4000 /$ transatlantica. 5724

ISSN : $1765-2766$

Éditeur

Association française d'Etudes Américaines (AFEA)

Référence électronique

Marion Charret-Del Bove et Françoise Palleau-Papin, « Vanessa Place: An Interview In Paris »,

Transatlantica [En ligne], 1 | 2012, mis en ligne le 06 janvier 2013, consulté le 19 février 2023. URL :

http://journals.openedition.org/transatlantica/5724 ; DOI : https://doi.org/10.4000/transatlantica. 5724

Ce document a été généré automatiquement le 19 février 2023.

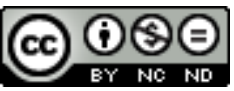

Creative Commons - Attribution - Pas d'Utilisation Commerciale - Pas de Modification 4.0 International - CC BY-NC-ND 4.0

https://creativecommons.org/licenses/by-nc-nd/4.0/ 


\section{Vanessa Place: An Interview In Paris}

University of Paris 13, Sorbonne Paris Cité, June $7^{\text {th }}, 2012$

Marion Charret-Del Bove et Françoise Palleau-Papin

\section{Introduction}

1 Vanessa Place gave a public interview at the University of Paris 13, Sorbonne Paris Cité, having flown in from Los Angeles the day before.

Of Vanessa Place and Robert Fitterman's Notes on Conceptualisms, Mary Kelly said, "I learned more about the impact of conceptualism on artists and writers than I had from reading so-called canonical works on the subject." Kenneth Goldsmith has called Vanessa Place's work "arguably the most challenging, complex and controversial literature being written today." Rae Armantrout has said, "Vanessa Place is writing terminal poetry."

Considered a leading practitioner of conceptual poetry, Place is also author of the novels Dies: A Sentence, and La Medusa, and a non-fiction book, The Guilt Project: Rape, Morality and Law, based on her work as an attorney representing indigent sex offenders on appeal. Her most recent work is available in French by éditions è e, as Exposé des Faits, and in English by Blanc Press, as the triology, Statement of Facts, Statement of the Case, and Argument. Place is co-director of Les Figues Press, and a regular contributor to X-TRA Contemporary Art Quarterly.

\section{Interview}

MDB: So we just wanted to introduce Vanessa Place. I think that maybe I can describe you as a two-faced person.

VP: at least.

MDB: at least from the perspective we had from your books. So you are a criminal defense appellate attorney. You told us that you worked first on gang cases and then on rape cases and it is based on your experience of rape cases that you wrote that book The Guilt Project. 
Rape, Morality and Law, which is one book which we are going to include within the questions we are going to ask. And so the second face among many...

FPP: I'll show the second face. Vanessa Place has written Dies: a Sentence, which is this marvelous book [showing it], little in terms of size only. It's a one-sentence novel about, let's say, a conflict to keep it vague. She's also written La Medusa, which is a major work, an absolute gem of a novel, which has a very different layout, it's much more fragmented.

Vanessa is the co-director of Les Figues Press, with Teresa Carmody. You contribute regularly to Xtra Contemporary Art Quarterly and your most recent work translated into French is Exposé des faits. In English it is published as a trilogy Statement of Facts, Statement of the Case and Arguments. And I believe your two faces do mix.

MDB: I was struck by the title of your book, The Guilt Project, and when I starting reading it, I noticed a reference to "The Innocence Project", which you define as "a non profit legal clinic at Yeshiva University's Benjamin N. Cardozo School of Law" (TGP, 50). Does the title echo that project?

VP: It echoes, well, it mirrors it, turns it around because the Innocence Project is concerned with people who are wrongly convicted, who are in fact innocent and who have been incarcerated. The Innocence Project tries to free them usually by way of DNA or some sort of new evidence that they hope to discover and put before the court and get the wrongly convicted-the innocent-freed. My feeling was that first of all, everyone I'm representing is guilty because they've been found guilty, that is to say that legally they're guilty; and second, in a kind of bigger sense and a more metaphysical sense, part of what is wrong with the U.S. justice system is that there is this emphasis on innocence and unless somebody is factually innocent, there is this notion that they don't deserve to be represented or represented fully. I think this is a little bit of an adolescent position such that if you do believe in the law as a structure, then it has to be applied as vigorously to the people who you know are factually guilty and that most of my clients are factually guilty and so now what?

And then I became interested in what does guilt mean in fact, and if I may go one step back, ultimately all guilt is, is a term of rhetoric, just like all innocence is, is a term of rhetoric. It's not a fact about anyone, no more than guilt is a fact about anyone. And so in the book what I was trying to do is to look at different forms of guilt in terms of factual guilt, legal guilt, cultural guilt, starting with a look at DNA, which is a question about factual guilt or innocence. And then go all the way through to the people who are guilty in every way and then what do you do with those people? And my joke of it or the sort of more farcical thing was, well it's easy if they are innocent. What's hard is when you really represent someone who is guilty; it's so hard to win.

MDB: If you represent those clients who have been found guilty, what are the most common grounds for appeal? Some cases in The Guilt Project were about a violation of the $8^{\text {th }}$ Amendment protection against cruel and unusual punishment? Is it the most common ground for appeal?

VP: No, in sex cases there are two frequent grounds for appeal, one of which is more successful than the other, but one of the more common grounds is the admission of evidence that was too prejudicial to the case. That does not work as often as I think it probably should. The other common one, and I can go back to the first in a minute, but the other common one that's probably more successful in California is sentencing. Sex sentencing laws are very elaborate and judges get them wrong all the time. So what ends up being perhaps the most successful basis for appeal is that there has been problem in sentencing and part of this is because sentences are so huge that it becomes very easy to make these mistakes and people get very sloppy. Sometimes 
you end up with stupid victories. I've had people's sentences cut half-from 300 years to 150 years. So it's not that it makes any actual difference. The reverse of this was a case where the client's sentence had to be doubled, and I had to tell him that his sentence had gone from 250 years to 500 years. On the one hand I can't really take that as a loss but perhaps I should. I had an interesting argument with someone about whether these issues or cases were worth appealing, in which I discovered again how absolutely structural my position is. In other words, part of my job is to reassure the public that their interests are protected from the State-no matter how stupid or worthless an individual defense may be.

One of my fundamental objections to the current legal environment is that because my clients are so universally despised, there is a tendency in the prosecutions towards "overkill," where the Government wants to bring in everything, every bad thing these persons have ever done or are accused of maybe doing. And you really don't need this sort of thing by and large, mostly the evidence of the offense at hand is enough, so I think there is a certain kind of mythic character to it, a confrontation with evil that becomes a fetish.

FPP: That ties in with my question: in terms of literature, even though you deal with it very differently, that ties in with the murky zones of guilt and the fascination with evil that you find in American writers like Hawthorne and Melville onward. How do you relate to those old forefathers?

VP: Well relating to the older ones is easier than relating to the newer ones because again there is a weird thing that happens in American literature where it becomes progressively stupider as it becomes more and more American in this very strange way. It discovers a kind of native naïveté at some point whereas if you go back to Hawthorne and Melville, especially Melville, it's much more complicated in terms of notions of guilt and then something happens around and after Modernism, a kind of a chasm that happens right where the Americans become sort of nouveau Americans or something. But Melville is particularly interesting with his "Benito Cereno." That's a great story of guilt. Poe's Pym is another one that's marvelous about American guilt and the complexities of that. But what those stories had is the embeddedness of guilt, guilt as part of innocence. There is a spectrum and we denote points on the spectrum, but we denote points on the spectrum as a convenience in a way, as a categorical mode as opposed to being an inherent propriety of the thing itself, which I think Melville brilliantly brings out, just as Moby-Dick is one of the great postmodern novels before postmodernism. But that's what it also is, a play on the scales of guilt.

FPP: Yes, I forgot to mention in my too brief biography that you had written Notes on Conceptualisms. It broaches on all these subjects for me intriguingly because it's fragmented and very thought-provoking but not laid out as a kind of narrative. So this is just an addition.

MDB: What about the notion of guilt? Because it seems to be central to your work and particularly The Guilt Project. So we were wondering whose guilt it is exactly. Is it the State's guilt because you seem to want to shed light on the deficiencies of the system that you described as "a cultural and legal stew" $(T G P, 3)$ ? Is it our guilt as well because we are all watchers of the drama and sometimes accomplices, aiding and abetting the "overkill"? Is it a more general sense of guilt? Is it also a form of catharsis? What is your own part of guilt for representing that kind of categories of people?

VP: Yes. Yes.

[laughs] 
MDB: At the origin it was yours, maybe?

VP: No-It's all of the above because the law is a fiction and we all agree to believe in the fiction. We pretend as if the fiction's real and thus it becomes real. It's like religion in that way. If I kill people in the name of something, it's the real thing. It doesn't matter beyond that, and the law is the same: if I stop at a sign, the sign stops in fact-though the fiction continues. But for me, that's what's interesting in a lot of the work that I do, for example in Exposé des faits, or in the trilogy in which I selfappropriated my legal briefs and presented them as poetry and did not change them at all, or in any poetic way.

For part of it, in all of these works, is letting the structure show through as structures because structures are a) structural and b) convenient and c) fabricated. So the structure of guilt was one of the things that I was very interested in letting show through, but it's a shared guilt certainly.

It's a shared guilt, but then I'm not quite sure what the original sin is, except for this need to ascribe guilt. And certainly with the clients that I represent, and this goes back to the evil question, I definitely believe that there are people who are evil. So I'm not one of those very ethical defense attorneys that for each one of my clients says "that poor guy" or "that's not right", but at the same time, for me the absolute fact of that evil is also very matter of course. And the more interesting ethical position. In other words, it doesn't surprise me that's the case so then the question becomes not to act in horror or act as if that evil is a separate category, but to see what are the choices that are made, what are the possible ethical choices that can be made in relationship to that evil. And in my poetic work I'm very pro-evil.

FPP: I'm not so sure about that. So we prepped up a little bit and we are desperately trying to get Vanessa to expand on some of the answers.

MDB: Let's turn to our next question. There was an expression I particularly liked. This is when you described the situation of those who have been described as sexually violent predators (SVP). They are trapped in "legal limbo" (TGP, 69), which is true because they are just indefinitely kept somewhere, not particularly in jail but somewhere. They don't even have the possibility to be released on parole and you said that the situation "appeals to the desire to shove nightmares into the closet and bolt the door." (TGP, 78). So is your book a way of opening the doors of this closet where we shove our worst nightmares? Is it a way of opening because you focused on exposure? How would you describe that?

VP: "Opening the doors" feels a bit liberatory, which seems overtly optimistic. What's significant about the idea of sexually violent predator is, on the one hand, we know that there are people who are predators and who will repeatedly commit the same kind of sex offense and we also know that statistically that's a rarity. But the rarity of it in no way stands in the way of this desire to keep people indefinitely. So it's not so much opening the door, I would say, as cutting a window into the door to make you have to see this, the desire to lock these people up, all of them. The only way, and I think I've said this in the book (TGP), the only way you have a $100 \%$ guarantee that no one will reoffend is never to let anyone out. In other words, if you had a system where you actually were trying to determine who is going to reoffend and who is not and you let out, let's say, $50 \%$ of the people, if out of that $50 \%$ a thousand never offended again and one person did, then the argument in some way should be that your system of deciding who gets out works because out of a thousand only one person reoffends, but that isn't the way it works. The way it works is that if one person reoffends, that thousand should never have been let out. That's the part that I 
find morally offensive because what's happening is that you have these lives that are disposable and are disposed for our comfort. And we are fine with that, we're fine that those thousand people would never be free although they don't pose a significant danger of reoffending. And those people are sacrificed to our psychic comfort and I think that is contemptible. It's no opening the door to the nightmare, it's forcing you to see that it is your nightmare. So you may wake up with your heart pounding but they aren't actually after you. The reaction is purely one's own and that's the culpability that we share. We are willing to sacrifice people to our nightmares.

FPP: It's a great answer and now we understand your previous answer better because you had written "shoving you inside" this closet where we shove our worst nightmares. Thank you. We still have a couple of technical legal questions. I hope you're fine with this.

MDB: The next question is linked with the previous one. You said that we have those disposable laws. What you seem to argue in the book (TGP) was that the State, in fact, has to justify the application of its laws and its system and I had one question, which was not among the questions we prepared before. How do you reconcile the necessity of the State to justify the application of its laws and procedures with the use of DNA and the fact that it's not like a pregnancy test, providing a clear-cut answer (TGP, 33). It can't tell you if it is yes or no. You have some doubt, in all the cases, at least all the cases you presented, that there was "reasonable doubt"; so people should not have been convicted as harshly as they were. How do you reconcile the increasing use of DNA, and scientists being looked up to as gods sometimes, and the fact that the State still uses that.

VP: DNA is hard, and I say this in the book. The fundamental difference between law and science is that science always deals with probabilities and generalities. If it's true in $99 \%$ of the cases, science will say it is true, that is to say, correct. Science also can turn around very quickly. If there's a new discovery, a new theory, science changes its mind. The law is like a battleship. It turns very, very slowly. And the law is not to think "in the main." That is to say, as a defense attorney, what I'm always interested in is that one percent. So even though it's true in $99 \%$ of the cases, my client is not that $99 \%$. Anomaly is always the argument. DNA is a really useful tool as a matter of investigation, but this is where it gets difficult for me: if you've got a DNA analysis that indicates that I am a possible contributor to the forensic DNA (the evidence at the scene or on the victim) and you also have a victim saying "I remember. It's her" and you also have the fact that I was last seen a block away by a flock of priests and police officers, then you start having less and less doubt as to my guilt, but when all you have is the DNA and the victim that I'm accused of raping for three hours can't recognize me, and I've got a fairly solid alibi, then suddenly the significance attached to DNA evidence-which is, it should be remembered, an interpretive analysis of data -seems misplaced, the emphasis is failing because the presumption is that of innocence. So the stress should not be falling on the scientific test, which maybe a perfectly good scientific test but doesn't deal with the exception and the law is always about what's the exception, or should be, because the law is concerned with the individual, not the type. And, again, the stakes are so high. I've been solicited, so to speak, to do death penalty cases. I don't want to do them for a couple of reasons. One is that I have no interest in escorting somebody to the death chamber, which is what you do ultimately, given the rate of reversals, but two is that in some ways, in death penalty cases, people understand that the stakes are very high, but with sex cases, they're still considered to be just regular cases. Perhaps a little bit higher because the sentences are rather severe. But it's more like a slow death sentence, as 
most of my clients are going to die in prison, almost all of them, one way or another. They're either going to die of old age or somebody is going to kill them. And that's why when you start having such an emphasis on a scientific test to the extent that DNA trumps even things like the victim's own testimony, then I start to think we shouldn't be reifying science in this way; and prosecutors have similar problems when there is no DNA evidence, suddenly juries will say "where is the DNA evidence?" We had a criminal justice system before we had DNA evidence. So there has to be a way to deal with it.

FPP: They're heavily influenced by television.

VP: Yes and it's also a means of absolving themselves from their responsibility. If there is a test and the test says he did it, then fine, we just check the test. I actually know a bit about DNA and DNA is somewhat complicated and it took me several complex DNA cases and having to read a lot about DNA analysis to understand the way it works. I can't imagine somebody sitting in on a week-long jury trial really being able to evaluate a DNA test critically, and so you end up voting for which scientist you think sounds smarter or makes it more understandable to you. More understandable being almost always more reductive.

MDB: accessible

VP: yes, accessible. They like experts who say it is like a pregnancy test. They love that because it's very comprehensible-but once they get in there and start talking about artefacts, false positives, stutter, and things like that-

FPP: so the buzz words get in there.

VP: Well, it's like anything else, to read something critically is harder than to just say Moby-Dick is about a whale, all right fine and now I don't have to read it. [laughs]

MDB: There is something you mentioned earlier, the fact that the law is a fiction, "a legal construct-a fiction that substitutes for fact" (TGP, 134), so it is based on fiction, fiction for facts. There are lots of facts in TGP. We were wondering if the mingling of fact and fiction is one of the reasons why you started writing works of fiction, books and novels, if you wanted to reconcile both, if you think that there should be no frontier between the two because they are one and only.

VP: More the latter. In fact, I started writing before I started law. So I found my vocation for my avocation or vice-versa. It occurs to me all the time. One of the funniest things in the world is the crosswalk sign, you know this light goes on, this little image that we take for a hand, and we all "stop", because we all decide that we are going to believe in the fiction that if a certain light goes on, we can't walk or we can, we make a choice. Žižek says "You know you're part of a culture when you know which laws you can break", that's the true knowledge of a culture, not which ones you have to obey because that's stupid, anyone can know that. So the question becomes what are the deep laws, the deep fictions we realize, and how can one refuse to obey these. Why I started doing appeals? I did trials very early on and found them intellectually unsatisfying because a trial was mostly performance. It was fun but it didn't have that same working through the maze, the sur-and under-ground labyrinth, and what I liked about appeals was there's a way in which you're working within a fiction and you're writing a fiction at the same time and thus building a fiction. So I would caution the word "fact". Fact in law, and this is what Expose des faits points out: in a criminal appellate brief, in California anyway, there are three sections: there is statement of facts where you present in a narrative form, like a 
story, the testimony at trial; then there is the statement of the case, which is a procedural history of the trial, then there is the argument. Well, if you start to think about what's a fact then, in law, a fact is something that a witness got up and testified to and certain significant people believed. Does that mean it happened? Does that mean it happened exactly in that way? What I would say is it doesn't matter if it's true or a matter of fact, it matters if it could be true. That's what a fact is. It's something that we know could have been true because people voted and believed in it as a possible truth. It could be a complete fabrication, it could be a partial fabrication, it could be no fabrication at all. We don't know, we'll never know; all we know is that what counts as fact is that twelve people have said "I'll vote for that one." So, that's what our facts are based on. More, that's what our conception of fact comes down to.

FPP: If I could just say how that intersects with La Medusa. You call trials "the show", so a performance. I'm curious because there are several passages, long inserts, in which you mentioned a young lawyer who began there. How much of this did you work from biography? How much of the facts are your personal history?

VP: Some. All of it is in there. But then there's also history bits in there, and within the history bits I would throw in things that are complete fabrications but served in the same register because history is another fiction of some grander variety. In this sense, history is like tourism; it's just what's popular, what's revisited, and this becomes history. Then another place becomes more popular and that becomes history. So there's definitely bits. I'm interested in how rhetoric works to shape, how rhetoric is shaped and works to shape. In Notes on Conceptualisms, we came up with the idea of the sobject, a senti-mental combination, that you can no longer have this idea that there is a subject and an object, that individuals exist as sobjects in the world. And I think that is an algebraic, formal notion of that entity.

FPP: Just for those who may not have read La Medusa yet, the history parts are mainly about the history of Haiti because a bunch of characters are a Haitian family living in Los Angeles and so there is a very interesting way of going in depth in terms of time and on the surface in terms of their displacements in the here and now as a family. I found that interesting in particular for us French readers because it echoes our own history of colonialism.

MDB: There was one keyword that you used: trials. Are your different works of fiction to be considered as a form of trial in any sense of the word because we have different meanings of trial.

VP: Trial by ordeal.

MDB: Trial by ordeal. You refer to the way people were tried in the past, some were burnt alive, some were drowned. And nowadays when they are tried, this is an ordeal as well. The reading of Dies: A Sentence was an ordeal for me because reading through a book with only one sentence, I had the impression that I had no space to breathe, it was really physically hard, and it was an ordeal. Was it designed for that? Was it written as a way for the reader to go through an ordeal, through a trial?

VP: Well it was written... there are two things. One is that it was written between drafts of La Medusa, so it was more of a private thing. Having to deal with these fragments all the time, I just wanted to break from dealing with fragments. I tend to be a formalist in my heart of hearts, and so I thought, what's the opposite form of the fragment? It would be the single sentence. And also with the fragments, the trick is to be constantly holding them together and with a single sentence, the trick became how can you have it continually falling apart but also have it so that the comma 
works as a hook that keeps you going, so it functions as a single sentence. So it's not cheating as a sentence. And then in terms of form and content because as Medusa is very much about a kind of expansive historical geography, then Dies became about conflict or war or some sort of thing like that, it had to have that kind of ordeal, claustrophobia, the inability to step out of this situation. So there was that. In a bigger way I find everything to be some sort of trial, in both senses, and I imagine in many senses. These are all indictments of something, all attempts, necessarily partial, and all performance, and performance hopefully of things that have a certain stake. I'm not really interested in writing or dealing with things that don't have a kind of ontological heft.

FPP: Just to follow up on that. It's interesting because even though those novels are often opposed, I mean one being concerned with fragments and the other one being one long, rambling sentence, I found a passage in La Medusa dealing with police brutality that echoes one of the passages of The Guilt Project very much and that whole section is just one sentence, so it works in the same way, and even if it's only a couple of pages, it works exactly in the same way as in Dies: A Sentence. I'd like to go back on this a little. Dies is described as a war narrative, and that section from Medusa about police brutality also deals with a war narrative like Dies, and form and content then cohere. Could you develop on why one sentence for this particular episode?

VP: I think part of it is that at least when I write violence in the law, when I do it in my briefs, there's a way in which because of the form, it favors the simple declarative sentence. The law likes the simple declarative sentence. Americans like the simple declarative sentence. I'm not a particular fan of the simple declarative sentence, but for anybody who's experienced violence, or the Real in a genuine way, there's a certain way in which it feels inevitable as it's happening, and also inescapable. And the long sentence, the sentence that has some sort of subordinate, whether subordinate clauses or dependent clauses, is causal. And when you are in these extreme situations, they feel causal even when they're not. Not to get too large about it, but I think that's why the hardest thing for people to understand is that so often the reason that violence occurs to them has nothing to do with them. Not that it's random, it's like winning the bad luck lottery, there are things you can do to increase your chances of winning the bad luck lottery, but ultimately it's just a lottery. For the clients that I've had that are predatory, that window was open. If that window had not been opened, it would have been the other window. So the sentence is served on both sides, by the victim and the perpetrator. It's just the causes that are different.

FPP: It's enmeshed and enmeshing.

VP: It's a system. And it's a narrative of sorts, but it's a mistake to think it's a narrative that only one side has. Getting back to the predator notion again, I said in The Guilt Project that when there used to be witch trials, there were witches, right? There were. I mean, there was a society that believed in witches, so they had witches. We're a society that believes in sexually violent predators, we have them, we can show you them. We have tests, they had tests, so they exist, but it does not mean that in fifty years, they'll exist, or we won't look back and say they were our witches. And even though I'm sure at the time we were burning people for being witches, there were people casting curses on other people, now it does not seem to be quite as severe a problem.

FPP: Well, depending where.

VP: Yes, right. [laughs] 
FPP: Now a mixing genre question. In La Medusa, there is that incredible mixing of genres. There's script $(L M, 294)$, there are narrative sections $(L M, 295)$, some parts are a question and answer session like a catechism ( $L M, 317$ et sq.), some are more like theater ( $L M$, 286-94), others offer snippets of definitions (in bold, $L M, 298-99)$, fairy tale $(L M, 283$ ), etc. What's going on there? Why the need to vary the forms so much for this type of narrative?

VP: Part of it goes to the conceit of the Medusa, which was the idea of the head that has many heads, and so each one of these heads would potentially have a different genre, would be articulated in a different way. So you've got the many heads of many characters, but then also the many heads of different genres, which is another narrative device, or expository device, and it fits very well in Los Angeles, which is a very decentralized, many-headed kind of city. But also, to my mind, towards the end there's an image of if one thing, it's about the brain, and the coils of the brain uncoiling in a Medusa sort of fashion. It gets into the notion of the sobject. A lot of traditional novels begin with interior perspective which then widens out to the world so there's this notion of the single subject that is encountering the world, whether that's the protagonist that's cast in the third person or the closer "I". And with Medusa, the idea was to invert that structure, or reverse the structure. It starts with all these multiple ways of apprehending the world, that then begin to maybe concentrate into a single subject, but the subject is a bit false, because like Medusa, it's composed necessarily of all of these other heads, which seemed more accurate in terms of describing at least how I experience the world. It's being less about, you say being colonialist, but less for me the stain of striding out confidently and understanding and taking in and synthetizing, versus, there's a lot of information all of the time, and some of it is generated by me, and much of it is not, and some I retain, and some I do not.

One of the things I was interested in with Medusa was also, how is this not a postmodern book and also not a modernist book? What are the ways in which it differs? Unlike Modernism, when you have multiple voices or multiples languages it was expected that you understood them, that was again the single subject, that if there were some passage in Italian, then it was because everybody, of course, spoke or could read a little bit of Italian. With Medusa, the idea is that we who live, most of us, in urban or cosmopolitan areas encounter languages all the time that we don't understand, and we don't bother. It's another head that we don't particularly comprehend, but it passes through our field of experience. And unlike Postmodernism, which I think retained this idea of the imperial subject, that could sit above and periodically let you know that it was pulling the strings, but did so from a position of mastery, the authorial subject in Medusa is as subject to all this other stuff as anyone else.

FPP: Thank you. You go way beyond our questions. That ties in well with our question about your use of languages. While some of the characters may not understand each other's languages, I feel that at least a narrative voice does: there are incredible crosslinguistic puns in the novel, between French and English, or between German and English, or German and French. One French example: "mis-en-trope" (LM, 471), between a misanthrope and figures of speech. Those are moments of contact that click, in spite of the linguistic fragmentation and the loss of mastery. Could you expand on this love of language and punning?

VP: I do love language. Language, to me, is seen as the paint. Sometimes you just play with the paint and see how far you can do that. Whether people, so to speak, "get it" or not... It's nice if they do, it's great, because it's another level, but it's also on the 
surface, and it's just part of the stuff you're dealing with. It's the same with the law. All law is, is language. So how much can I do with this material? It's the great pleasure of it, and the great danger of it, both. I do a lot of appropriation work, and one of my secret indulgences is, periodically I like to go over and play with the paint.

FPP: With sounds...

VP: With sounds... One of the things that I saw recently and I thought was so great was this man who does these poems that are what he calls "Chinglish". What they are is a series of sounds and if you are a native English speaker and you hear this series of sounds, you'll hear a poem in English with a Chinese accent, about a boat or something like that; if you're a native Chinese speaker, and you hear the same series of sounds, you hear a poem in Chinese, with an English accent, about a butterfly. It's the exact same series of sounds. This was one of my favorite things to think about, ever. Because that's the great thing with puns and the jeu de mots, that's the great part, when you hear something, and it's like a sculpture, it just depends on which side you're coming to them from. And so how can you do that? What's language for, if not to make stuff, make little things that work many ways?

FPP: Just to go on from sound to typographical layout. To pick an example, let's take page $202(L M)$. There are different voices within the frames. Sometimes the frames overlap, sometimes there are signs that indicate certain inserts. Sometimes an insert over text will hide a portion of the text, so that in a paragraph, there's something missing that we can still skip over and guess what it's about. We're not completely lost, yet this is fairly unsettling. Why such layouts? Is that a way to work with several centers of consciousness?

VP: Yes, and it's also about the frames, because part of the book has to do with television and seriality and this idea of the frame itself. The frames have a consistency throughout much of the book, they signify. As the book goes on, that signification starts to fall apart, because the separateness of the voices starts to atrophy, and so the box starts to collapse a bit. There are sections where frames should be false and interrupted by other frames, because that's true. The way I see it, books are a medium. The page obviously like a canvas, or something like that, set in a grid, which is always a kind of narrative. So how do you operate within the space of the page, looking at it like a topographical space? One of the things people can be very stupid about is forgetting that the page is a visual unit. And thus has negative and positive spaces, which may or may not be white space. We live in an age now where the divide between text and image-there really is none, the text is an image, an image is a kind of text. A text-image could be full of content, like a figural representation, or more blank, like a background. This could be represented by textual immateriality or irrelevance, for example, in addition to the literality of emptiness represented as such. There's a project I've been working on for a number of years, which I think will make Medusa the most legible of all of my works. In this project, I'm putting in every kind of writing I can think of, but also thinking about the book as an installation site. So if I look at a book as an installation, then what can I do within the frame-spatial and temporal-of this installation? That sort of thinking started a little bit with Medusa and trying to think about the frame of the page and then frames within the frame of the page. And how long it takes to look at a series of frames. 
FPP: Even though your pages often look like they could be taken from e-literature pages, you chose to freeze the click. They are on paper.

VP: Right. Well, what does Medusa do, after all?

FPP: It freezes the click?

VP: Won't you look at it?

FPP: Right. But doesn't it also slow down the process, as it forces us to look at it? If it clicked, we would be going off on a tangent.

VP: Right. But that's the nature of this medium, it's a frozen medium. It doesn't force you to do anything. You can throw the book across the room at any given moment. One thing that's interesting about the book as a medium is that every medium has the thing it's given and the thing it has to fight against, because the book as an object is designed to be gone through like this [demonstrates]. What it's given, then, is temporality, unlike a canvas. What it's always fighting against and trying to achieve is simultaneity, which is very difficult for language and for the book. In using these frames, part of it was to try to invoke a kind of simultaneity that is otherwise not available in most traditional books. To interrupt frames with other frames also pushes that notion of the simultaneous.

FPP: I was tickled in La Medusa by the sense of frustration sometimes because you suggest a link, say "insert map of L.A.", for example, and there's no map, no insertion. Do you work from frustration? To create desire, maybe? Do you play with frustration?

VP: I like to set up invitations and temptations. Especially in my conceptual work. What I say in my conceptual work is that this is all about you. This has nothing to do with me. All of these things are ways in which I feel I'm inviting the person who encounters the work to discover a little bit more about themselves and what they want and what their expectations are, so that the frustration is not my projecting a frustration on to you. When you see "insert map", do you insert a map? Do you expect a map to be inserted? Do you want a map to be inserted? Is that a map itself? There's that part of it too, I'm interested in seeing what happens on the other side more. It's a world in which we can leave opportunities open. That book in particular is very full, so what are the places that it can open itself up?

FPP: To pick up from your space metaphor, to me this is one of the best books about L.A., or my idea of L.A., to which I've never been.

VP: If you went, it would be just like that. [laughs]

MDB: You were talking about frustration and how you tempt your audience toward meaning through invitation. Do you also tempt your audience through a strategy of blurring frontiers? I was struck, when I read The Guilt Project, by two very short sentences, "the monster who becomes a man" (TGP, 78), and "they are us" (TGP, 124), so the idea of the mirror. They and us, we are alike, whereas we thought we were different, and the monster, that beast we want away, in fact becomes a man, so he's very close to us. This is a way of blurring the distance between the two. Is it also part of temptation?

VP: In that sense, what I'm pointing at is that there's been a temptation that's been succumbed to without thinking. I remember seeing some quote by Salman Rushdie not that long ago, where he talked about "these people" and he said that there were people who needed to be taught how to be human. I thought, that's fairly contemptible, that he's still engaging in this idea that there are some human beings who are not human. It's a pretty horrifying stance to take publicly, and to take publicly without apparently noticing that this is a contemptible stance. In The Guilt 
Project what I was doing was being very overt about saying "this is false." This precept of the inhuman or monstrous is entirely false and contemptible. It should be constantly understood that the desire to have a separate category is a betrayal, that you're most in the categorical evil at that point. I have a very good friend who is a Lacanian analyst-who doesn't? [laughs]-we have the best time!-but one of the conversations we were having just yesterday was about how, because of the work that I do, I have met true sadists. Not pretend sadists, or leisure-time sadists, but true sadists. Because with true sadists, it's not consensual. There's no contract. In fact, in the moment when it would become consensual, the true sadist would not be interested. To my mind, as soon as we set up these categories, we've become the monster, because we've become the true sadist, where we don't care what the other person thinks, what the other person's humanity is like, what it's like to have that particular flaw in your genetic make-up, or to have that particular childhood trauma, or to have that particular combination of the above that leads you to think that raping an 80 year-old woman is a really good idea. I had a client who was a serial rapist of elderly women, who was also probably the nicest client I've ever had, because for him, he existed in these two worlds. He had an us and a them, it's just that they both happened to be inside of him. When I'm confronted with that person, what he wants is for me to do what everybody does, which is to separate those two sides of him. In my dealing with him, what I want to do is actually have to see him as he is. And that, to me, is the more radical gesture, ethically and aesthetically. To live in these worlds in which things are not considered to be contradictory but simultaneous. Not unlike the trinity.

I said to you yesterday, one of the great things (great meaning large, not terrific) about the United States is that the United States cannot exist without racism. This is the big secret about the United States that it won't tell itself. It keeps pretending that racism is something like cancer, maybe we can get rid of it, instead of its digestive system. If the United States is ever able to deal with that or to think of that as systemically, then maybe... But until then, we're just going to keep putting new clothes on the same problem and pretending it's something else.

So for me, with my aesthetic work, what I'm interested in doing is creating these situations that tempt people; what I'm interested in is having people make decisions for themselves about what they want ethically and aesthetically. I don't want to tell them, because whatever they choose, they choose. It could be pernicious, it could be horrible, and it could be something I think is just great. It really does not matter. Because they're the ones that go out and live their lives according to that. So if you want to believe Salman Rushdie that there are certain men who are monsters, that's what you'll believe, but you'll have to understand that then you are a monster. That's what you've chosen. What I always want to do is create the situation in which one makes the choice. Which is a little false, but that's right.

FPP: Also, this is revising master narratives, certain arch-American narratives. You revised Gone With The Wind?

VP: I've been doing a whole bunch of things like that.

FPP: When you revise such a narrative, you also invite us to look at it anew.

VP: I have an extensive Gone With The Wind project. Along the same lines, there's a book coming out this autumn, called Boycott, where I adopt Lacan's maxim "La femme n'existe pas" and marry it to-there's an American conceptual artist named Lee 
Lozano who in the early 1970s stopped speaking to women [laughs]-to Lozano's 1972 "Boycott Project."

So I did this boycott series where I take these iconic feminist texts and replace all references to women with their male equivalent, so they're only about men, there's no women in them at all. They become really fascinating, because as you're reading them, you find yourself constantly grappling with the issue of gender in a way that you never do when they're about women. It's very upsetting. I've done a couple of chapters of de Beauvoir-de Beauvoir is really good for this revisionist treatment [laughs]. There's a small book out now called "Fatherhood and the Child" and it reveals everything, beginning with the sentence "one is not born, but rather one becomes a man"... And I just did what just came out, it's online (http:// www.twoseriousladies.org/author/vanessa-place/ ${ }^{1}$ ), I redid Cixous's The Laugh of the Medusa, only changed it to The Laugh of the Minotaur, and so it's things like: "It has come time for me to write as a man... I am a man... I must write the story of men..." But when you're reading de Beauvoir, for example, it's very interesting because I would find these simple sentences, and suddenly didn't know how I felt about them. When I read or write: "Puberty is a very difficult time for the young boy", I would think: I don't know. "The first ejaculation is a traumatic experience... It is the dream of every young boy to become a father." All of these points became points of confusion. Suddenly I was in a world where gender wasn't essentialist, but also it wasn't entirely constructed, and I was having to build it or re-build it myself, because I didn't have two genders to work with, I only had one. Taking Irigaray's "The Sex That Is Not One" is what these texts ended up doing, though doing it through subtraction. The Boycott project became very interesting to me as, again, this invitation as pure or impure participant, to have to engender in a different way. It was a very internal thing. With the Gone With The Wind project, I keep trying to get sued by the estate of Margaret Mitchell, because that would then finally finish the thing [laughs]. I have these series of interventions. It's still a beloved book in the United States. In fact, the American critic Molly Haskell recently wrote a book about Gone With The Wind, calling Scarlett a great feminist hero. I've been tweeting Gone With The Wind for years now, 140 characters at a time. Casting the book into the winds of the Internet. A writer in Finland once told me in an interview the project would not be done until 2017. I have a book called "Gone With the Wind, by Vanessa Place", where I went through and found all the parts in Gone With The Wind in which the word "nigger" and other derogatory terms for blacks appear prominently and I've put them together in one text. And I really wanted the estates to say, oh, those are ours, you have to give them back now! Another piece involved taking one of the passages, if you're familiar with the movie or the book at all, there's a slave called Prissy, and she has a famous speech about "I don't know nothing about birth and no babies". In 2009, Poetry Magazine did a special folio on conceptual work, edited by Kenneth Goldsmith, and I submitted a portion of Statement of Facts, and they rejected it. It was the only piece they rejected. They said, "it's too violent, you don't tell the reader how they're supposed to encounter this material, like child rape." I said, fine. So I submitted this Prissy speech from Gone With The Wind, that I had set in Miltonic sonnet form. They had no problem with me appropriating a slave's ventriloquized language and presenting it as a poem. I thought that was an interesting ethical choice on the part of Poetry Magazine. My Gone With The Wind is constantly trying to emphasize the racist and American colonial elements in Gone With The Wind, and to 
see if it'll ever stop, or be stopped, but apparently not. Apparently, they're more than happy that I keep repurposing it. I also did a version of the book where I didn't do anything to the text, it just had the entire book Gone With The Wind republished with my name on it. I keep trying to explain that I'm stealing it, I'm not parodying, I'm not rephrasing, I'm not adding artistic value, I'm just stealing.

FPP: It that legal?

VP: No, it's illegal. It's wrong. [laughs]

FPP: Just one last literary question I'd like to ask about sources, in particular in Dies: A Sentence. I was wondering about your influences in composing in the form of a stream of consciousness narration. When I asked you previously, you answered: "Of course, Finnegans Wake, though that's like citing a sunrise. And The Unnameable, which would be the sunset. If I am, as I rarely am, perfectly honest, I was immersed in Shakespeare at the time, memorizing sonnets, working slowly through the plays, listening to recitations in the car. Dies was written very quickly, as befits a torrent. There is some connection with influence in that."

So I want to hear more about that. It's so different, and yet... Can you tell us more?

VP: There was a six-month period when I decided I needed to spend a lot of time with Shakespeare. Living in Los Angeles, it became quite easy, because every time I got in the car, I would just put in recordings, recitations of the sonnets. And then, I started memorizing some of the sonnets, because I wanted to spend that kind of time with them. The sonnets, to me, it's a monologue. If you take them as a unit, all hundred and fifty four of them, it's an ongoing stream of consciousness kind of narration of a story that has its turns and twists, and there's wordplay, and these little asides, and there's a mythic register and the overlay of Dasein. It's this scram bag of that contemporary society and their process of signification. The thing I'm most interested in, in everything, all my work, is the moment at which, and it's a little bit false to say it's the moment at which, because I think it happens simultaneously, but when the real becomes symbolic, becomes subjected to the symbolic order. In some of my more oblique works, or of my more open works, I would say what I'm trying to do is create that situation in which the person who encounters the work must make it symbolic. And like I've said, that tells you a little something about yourself. In Medusa, how does one take all of this stuff that is L.A. and that is contemporary society, and what symbolic registers is it subjected to in order to make it mean something? Something mythic, for example. One of the great things about the Sonnets is that it's almost like you're going through the factory at different points, where one moment, he takes the fact that the beloved is not going to have children or doesn't have children, and that has to become subjected to a kind of symbolism. Or the color of the beloved's hair. Each sonnet acts as this little factory of taking a moment of the real and subjecting it to both the symbolic and the imaginary order at the same time, but having it come out with some precise and expansive significance within each passage. But then there are these asides, Shakespeare's always great with the asides. And the asides contract and dilate as well. As a whole, it becomes an ongoing narrative of that engagement-which is the human project, perhaps. The difficulty that I have with the traditional stream of consciousness novels or soliloquies like Molly Bloom's (and certainly there's a ton of Joyce in Medusa), is that with Molly Bloom, it's still a single voice. It has a cohesion to it, a purposeful cohesion, and a narrative cohesion that's very strong. With Dies, I didn't want to replicate that same sense of tightness, I wanted more of the openness and the 
constant pulling apart that I saw in Shakespeare. And Shakespeare is a terrific sucker for a good pun! He'll drop anything just to run up and do a little pun and then come back, which I find so wonderful in a way that some of the puns of, say, Joyce, are just tighter, less fun. They're always serving a point. Whereas with Shakespeare, there's more a sense of the paint and the play of language for its own sake, its own pleasures, which seems sexier. There's a way in which Dies, as much as it's about something that's not supposed to be sexy, has a kind of libidinal current to it. If war wasn't sexy, we might not do it as much. There's that as well.

MDB: We'll try to give you one of our last questions, which was taken from something you said in The Guilt Project. You wrote about the aim of the book, saying that "This book aims at the bruises, the darker parts of the jurisprudence and culture of guilt and rape that should embarrass all of us, but haven't yet." (TGP 16). Has anything changed since your book was published in 2010? Have degrees of rape been introduced? Or lesser penalties for rape committed without malicious intent, which is the requisite wrongful intent needed to convict someone of rape? Has a more mature sense of responsibility been established for women, because you tend to say that victims are only treated as victims (in the infantilizing "rape by intoxication statute")? So has anything changed or evolved since the book was published and read by the American people and around the world?

VP: I don't think things have changed concretely yet, but what I do see is a sort of attitudinal shift. Some of it comes from exhaustion. There's been so much done. And now we have this whole other series of problems. Now we have all of these homeless sex offenders, for example. So it went from the problem of "oh, do you know the person down the street may be a sex offender" to now, we don't know where they are. Or there are huge pools of them living under a particular bridge. Not that long ago, there was an article in the Los Angeles Times about a hotel, apparently somewhat near Disneyland, that's full of sex offenders, because, coincidentally, there's no other prohibited spaces around it. It's a hotel that a lot of families that want to go to Disneyland go to. So it ends up being twenty-three families and two hundred sex offenders, which I don't think is what they intended [laughs]-consolidation, that is to say, or concentrating the perpetrators. Sex offenders tend to do much better when they have emotional support systems, family and friends, as opposed to just being with a bunch of other guys who like to have sex with children. And the public begins to reconsider. Similarly, I recently had a case where my client had been looking at the possibility of a 120-year sentence, and the judge imposed a 60-year sentence instead. The defendant had molested his stepchildren for a number of years, and the judge said, this is a bad case, but it's not the absolute worst case. I've never heard a judge say that, or it's been years since I heard a judge say that. I think there's a sense that the pendulum is starting to move back a little bit. What's frustrating for me is that I get tired of living in a culture where I feel so much of it is about these pendulum swings, and I get tired of living in a culture where I feel so much of the conversation is between, I call it, "sock puppets." And what I would like to see is a genuine attempt to deal with things like evil, and evil on both sides. One of the things that at some point must be addressed is complicity of victims, which doesn't mean that one should be victimized, but it does mean actually that one needs to understand that sometimes these things don't happen in a vacuum. Sometimes the complicity is cultural, and culturally complex, sometimes it's more individually psychic, and psychically complex, sometimes it's a matter of a child making the best of a very bad situation. And so how do we deal with that? If we could get to a more nuanced sense, then there would be the possibility of a more mature way of engaging with issues of guilt and all 
of that on a legal standpoint, but also on an aesthetic standpoint. I would like to see literature move past stories of middle-age angst, or stories of the youth, the young man with the feeling, any feeling. Again, I think there's been some sort of regression in a lot of literature to this desire for things to be very simple. Even among the avantgarde, there is an adolescent longing for purity, for purity of motive, purity of Poetry, purity of the snowflake "I." I think that's a dangerous desire. The more that it can be complicated and "complected," all the better, and maybe we're starting to see that happen despite ourselves.

FPP and MDB: Thank you very, very much. [invite audience participation]

Frédéric Sylvanise: I think that Salman Rushdie was talking about the Talibans.

VP: I knew it was a large group. [laughs]

\section{BIBLIOGRAPHIE}

PLACE, Vanessa, The Guilt Project: Rape, Morality and Law. New York, Other Press, 2010. (TGP)

---, Tragodia 1: Statement of Facts, Los Angeles, Blanc Press, 2009.

---, Tragodia 2: Statement of the Case, Los Angeles, Blanc Press, 2010.

---, Tragodia 3: Argument, Los Angeles, Blanc Press, 2011.

---, La Medusa, Tuscaloosa, Fiction Collective 2, 2008. (LM)

---, Dies : A Sentence. Los Angeles, Les Figues Press, 2005.

---, "Untitled : Red over Black, blue, Orange" in Trenchart : Material, Los Angeles, Les Figues Press, 2005.

---, Exposé des Faits, translated by Nathalie Perrony, Alfortville, è ${ }^{\circledR}, 2010$.

---, in collaboration with Robert Fitterman, Notes on Conceptualisms, Brooklyn, Ugly Duckling

Presse, 2009.

\section{NOTES}

1. BOYCOTT PROJECT \# 13 BY VANESSA PLACE. The Laugh of the Minotaur, Cixous (1975), an excerpt from a forthcoming Ugly Duckling Presse book: “I shall speak about men's writing: about what it will do. Man must write his self: must write about men and bring men to writing, from which they have been driven away as violently as from their bodies-for the same reasons, by the same law, with the same fatal goal. Man must put himself into the text-as into the world and into history-by his own movement. The future must no longer be determined by the past. I do not deny that the effects of the past are still with us. But I refuse to strengthen them by repeating them, to confer upon them an irrevocability the equivalent of destiny, to confuse the biological and the cultural. Anticipation is imperative.

I write this as a man, toward men." 
INDEX

Thèmes : Reconnaissances 